LRH: Brito, Moulton, Souza and Bunn

RRH: Microalgae as the Predominant Food Source in a Tropical Forest Stream

\title{
Stable Isotope Analysis Indicates Microalgae as the Predominant Food Source of Fauna in a Coastal Forest Stream, Southeast Brazil. ${ }^{1}$
}

\author{
Ernesto Fuentes Brito ${ }^{1}$, Timothy P. Moulton ${ }^{1,2}$, Marcelo L. de Souza ${ }^{1}$, and Stuart E. \\ Bunn $^{3}$ \\ ${ }^{1}$ Departamento de Ecologia, IBRAG, Universidade do Estado do Rio de Janeiro, Rua \\ São Francisco Xavier, 524; Rio de Janeiro, RJ, Brazil, CEP 20550-013. \\ ${ }^{2}$ Corresponding author, moulton@uerj.br \\ ${ }^{3}$ Centre for Riverine Landscapes, Faculty of Environmental Sciences, Griffith \\ University, Nathan, QLD, Australia, 4111.
}

\begin{abstract}
Stable isotope studies of food webs in floodplains, large rivers, mangrove, and seagrasses have shown that, although a large proportion of the biomass may come from higher plants, microalgae provide a disproportionate amount of carbon assimilated by metazoan consumers. Evidence is building up that this may also be the case for streams, especially those in the tropics. At the level of individual consumer species we also see that the apparent diet may not be reflected in the carbon assimilated. Tropical streams commonly have omnivore-detritivore species that potentially show this phenomenon. We tested these concepts in four moderately shaded sites in a stream in well-preserved Atlantic rainforest at Ilha Grande, Rio de Janeiro. We sampled aquatic insects, shrimps and fish as well as potential terrestrial and aquatic primary food sources. Carbon stocks from terrestrial sources predominated over carbon of algal origin ( $>99 \%$ of total). The primary sources of carbon showed distinctly different isotopic signatures: terrestrial sources had $\delta^{13} \mathrm{C}$ values close to $-30 \%$, microalgae were $-20 \%$ and macroalgae were $-25 \%$. All fauna had $\delta^{13} \mathrm{C}$ values consistent with a carbon source derived from microalgae. Baetid mayflies and atyid shrimps exert a strong grazing pressure on periphyton and organic sediments but appear to assimilate predominantly microalgae. The palaemonid shrimp Macrobrachium olfersi also ingests large amounts of detritus of terrestrial origin, but apparently assimilates animal prey with algal $\delta^{13} \mathrm{C}$ signatures. These results support the growing view that tropical stream food chains are primarily algal based.
\end{abstract}




\section{Resumo}

Os estudos de redes tróficas usando isótopos estáveis em planícies de inundação, grandes rios, manguezais e pradarias marinhas têm mostrado que, apesar das plantas vasculares representarem uma grande proporção da biomassa, as microalgas fornecem uma quantidade desproporcional do carbono assimilado por consumidores. As evidências têm demonstrado que o mesmo pode acontecer em córregos (pequenos rios), especialmente nos trópicos. No nível de indivíduos, nós também observamos que a dieta pode não refletir o carbono que é assimilado. Nos trópicos, esse fenômeno parece ser mais comum devido à abundância de espécies onívoras-detritívoras. Nós testamos esses conceitos em quatro pontos pouco cobertos de um córrego de Mata Atlântica bem preservada da Ilha Grande, Rio de Janeiro. Coletamos insetos aquáticos, camarões, peixes e potenciais fontes alimentares primárias autóctones e alóctones. Como esperado, o estoque de carbono proveniente das arvores foi muito maior que o das algas $(>99 \%$ do total). As fontes primárias de carbono mostraram diferenças nítidas de $\delta^{13} \mathrm{C}$ : alóctone de $-30 \%$, microalgas de $-20 \%$ e macroalgas de $-25 \%$. Toda a fauna teve valores de $\delta^{13} \mathrm{C}$ consistente com os aqueles das microalgas. Este resultado foi inesperado para efemerópteros baetídeos e camarões atiídeos por estes ingerirem alta proporção de matéria alóctone e terem forte efeito negativo sobre os sedimentos orgânicos. Camarões palemonídeos (Macrobrachium spp.) também ingerem grandes quantidades de detritos de origem terrestre, mas aparentemente assimilam animais com assinaturas $\delta^{13} \mathrm{C}$ proveniente de algas. Estes resultados fortalecem a crescente visão de que cadeias tróficas em córregos tropicais são mantidas por microalgas.

Key words: tropical streams, food webs, stream fauna, periphyton, Cloeodes, Macrobrachium, Potimirim

Food chains in small, forested, temperate streams are generally considered to be based on allochthonous material -- the litter that falls into the stream from surrounding vegetation (Cummins et al.1973, Fisher \& Likens 1973, Vannote et al. 1980, Graça 1993). Assumptions that other aquatic systems are primarily based on allochthonous material have not always proven to be true, however, and aquatic sources of primary production, principally algae, have been shown to be important; e.g. Kitting et al. (1984) (seagrass), Hamilton et al. (1992) (Orinoco River floodplain), Bunn \& Boon, (1993) (billabongs), Forsberg et al. (1993) (Central Amazon River), Hecky \& Hesslein (1995) (lakes), Thorp \& Delong (2002) (large heterotrophic rivers). Relatively little research of this kind has been published for small, forested tropical streams (but see Salas \& Dudgeon 2001, March and Pringle 2003, Mantel et al. 2004, Douglas et al. 2005).

Preserved Atlantic coastal streams of the south-east of Brazil are often short, steep, oligotrophic and well forested (Por \& Lopes 1994). The input of allochthonous material, in these and in other similar Atlantic rainforest streams, was reported as seasonally differentiated and within the worldwide values for low order streams (Henry et al. 1994, Resende \& Mazzoni 2005). Brazilian rainforest terrestrial litterfall is similar to that of forested temperate zones (Haase 1999).

The importance of litter as a food source of forested streams is coupled to the limitation of autochthonous production cause by shading of the forest (Vannote et al. 1980); lack of aquatic production due to light limitation induces consumers to use the available allochthonous resource. This premise has not been extensively tested in tropical streams. Bunn et al. (1999a,b) showed that even well shaded tropical streams 
can have sufficient light input to sustain a reasonable level of primary production, and this was especially true in east-west oriented streams.

Aligned with the question of allochthonous input in forested streams is the role of shredding invertebrates in processing the material and incorporating it into the food chain. Many studies in temperate streams have described and quantified the importance of specialist shredding invertebrates (Cummins et al. 1973, Fisher \& Likens 1973, Graça 1993). Studies in the tropics have highlighted the absence or scarcity of specialist shredders in stream invertebrate communities (e.g. Rosemond et al 1998, Walker 1988, Dudgeon \& Wu 1999, Dobson et al. 2002, Mathuriau \& Chauvet 2002). On the other hand, studies have shown the importance of shrimps in shredding and processing litter (Covich 1988, Crowl et al. 2001, March et al. 2001, Wright \& Covich 2005). We must note, however, that the processing (shredding, fragmenting, collecting) of coarse and fine particulate organic matter does not necessarily imply the assimilation of this material into body tissues. Recent evidence has shown that xiphocarid shrimps may be functional shredders but trophic carnivores (March \& Pringle 2003). The palaemonid shrimp Macrobrachium hainanense also appears to shred but is trophically a carnivore (Mantel et al. 2004).

In flowing streams, surfaces rather than the water column are the site of primary production and incorporation of heterotrophic carbon (from dissolved organic carbon and fine particles). The periphyton community (or biofilm or epilithon) is grazed by smaller invertebrates (principally insect larvae and snails), and in turn by larger invertebrates (shrimps) and fish. Again, studies in tropical streams and rivers have highlighted the importance of the larger fauna as consumers of periphyton (shrimps Pringle \& Blake 1994, March et al. 2002, Souza \& Moulton 2005; fish - Flecker 1996; shrimps and fish - Pringle \& Hamazaki 1998). The phenomenon is not universal and insects were found to be important in experiments in Costa Rica (Barbee 2004) and in Brazil (Moulton et al. 2004). Again, the processing and removal of periphyton does not necessarily imply the assimilation of all of its components into tissues of the consumer (March \& Pringle 2003, Yam \& Dudgeon 2005).

Previous research in the region of our study sites showed that certain components of the fauna had a strong negative effect on periphyton and sediments of hard substrate. Experimental results indicated that organisms interacted particularly on the organic and inorganic sediments rather than on the algae of the periphyton. Baetid mayflies were found to be important in the regulation of periphyton and sediments at one site, (Silveira \& Moulton 2002, Krsulović 2004, Moulton et al. 2004). Atyid shrimps were found to have a similar effect at other sites (Visoni \& Moulton 2003, Souza \& Moulton 2005). At the time, we presumed that the baetids and shrimps were detritivores; the present study was designed to investigate this.

Analysis of stable isotopes of carbon and nitrogen can indicate the origin of sources of carbon and their flow through food webs (Peterson \& Fry 1987). Therefore stable isotopes have proven to be an excellent tool to compare what is simply ingested and what is really assimilated by consumers into their tissues. However, if the sources of carbon are too numerous and not isotopically differentiated, their contribution to consumers cannot be estimated (Post 2002).

We measured stable isotope ratios of carbon and nitrogen in food sources and fauna of a small stream in Atlantic forest to determine the relative importance of algal and terrestrial sources in the food web. We compared this to the stocks of carbon of the different sources and to site conditions. We had particular interest in the strongly interacting fauna of shrimps and ephemeropterans and chose sites with contrasting activity of these fauna. The sites also provided a gradient of altitude and shading. We 
included samples of the fish fauna, which we expected to be feeding near the top of the food chain and thus integrating the food sources at lower levels. We also sampled invertebrates of different feeding groups.

\section{Methods}

\section{STUDY SITE}

Córrego da Andorinha is a small stream in a well-preserved dense rainforest within the State Park of Ilha Grande Island (23 $04^{\circ}$ to $23^{\circ} 14^{\prime}$ S and $44^{\circ} 05^{\prime}$ to $\left.44^{\circ} 23^{\prime} \mathrm{W}\right)$ in Rio de Janeiro State, Brazil. The total catchment area of the stream is approximately 1260 ha with a highest point of $1030 \mathrm{~m}$ asl. The stream is about $7 \mathrm{~km}$ long and, for the majority of its course, has a steep bed slope. The substrate is generally well embedded, with large boulders and some sandy stretches. The geology is principally Pre-Cambrian granite; the water chemistry is oligotrophic (total- $\mathrm{N}=180 \mu \mathrm{g} / \mathrm{L}$, total- $\mathrm{P}=10 \mu \mathrm{g} / \mathrm{L}, \mathrm{pH}=6.6$ and conductivity $=25 \mu \mathrm{S} / \mathrm{cm}$ ). The stream empties abruptly into a small tidal estuary without a meander or transition zone. As expected of a stream in Atlantic coastal forest, considerable amounts of leaves and terrestrial material occur in pools and in debris accumulations retained between rocks.

We collected samples for stable isotope analysis in early February 2002 in four locations in a $330 \mathrm{~m}$ stretch from approximately 40 to $80 \mathrm{~m}$ asl (Table 1). The four sites each consisted of wadeable sampling areas of approximately $40 \mathrm{~m}$ of stream length, including pool and riffle habitats. A large waterfall at approximately $60 \mathrm{~m}$ asl separates the middle and high-altitude sections from the low stream section and acts as natural barrier to most fishes (Souza et al. 2001). The sites were chosen to represent places where previous experimental results had revealed different interactions of the strongly interacting fauna. The uppermost site was named Characidium. Previous work had shown that Potimirim shrimp were active in removing periphyton at a similar site slightly upstream from this site (Souza \& Moulton 2005). The second site, Mãe D’água, was approximately $123 \mathrm{~m}$ downstream and immediately above the waterfall. Previous work had shown that baetid mayflies were important grazers at this site and that Macrobrachium shrimp negatively affected this interaction (Moulton et al. 2004). The Bagre site was immediately below the waterfall, $71 \mathrm{~m}$ downstream of Mãe D'água. Preliminary evidence had shown that fish at this and lower sites acted negatively on the periphyton grazers causing periphyton to be more abundant (Souza et al. 2001). The Lambari site was a further $133 \mathrm{~m}$ downstream and $1.4 \mathrm{~km}$ from the mouth of the stream. We measured the base flow as $80 \mathrm{~L} / \mathrm{s}$ at Mãe D'água; no major tributaries enter the stream in the stretch of the four sites. We sampled in some other places in order to collect shrimp species that were not encountered in the four sites; they were found in the adjacent stream Rio Barra Pequena.

\section{SAMPLE COLLECTION AND ANALYSIS}

The geographic coordinates, altitude and dimensions of the sites were obtained by Global Positioning System and measuring tape. The stream forest overstorey density was measured using a spherical densiometer Model-C (Forest Densiometers, Oklahoma, USA). We averaged four readings facing North, South, East and West, at all sites. We measured the light regime at each point during a $24 \mathrm{~h}$ cycle using light loggers (Hobo light logger, Onset Instruments, Pocasset, Massachusetts, USA). We placed sensors at each site and at a completely open site, and expressed the result as percent full sunlight (Table 1.) The day of measurement was 20-21 August 2005; the sunlight was diffused by light continuous cloud during the period. 
We measured in-stream litter derived from the forest in August 2005 and periphyton standing stock in July 2004 in order to access and compare the biomass of in-stream food sources (Table 2). To collect litter, we set up four equidistant transects of $1 \mathrm{~m}$ width from one stream margin to the other, perpendicular to the thalweg in all sites, and collected all litter within the transect. The litter was then separated into four categories: leaves, twigs, branches and fine particulate organic matter (FPOM). Seeds and flowers were rare and included in the leaf category. We manually separated the larger material. The remainder was dry sieved through $1 \mathrm{~mm}$ mesh and retained on 0.25 $\mathrm{mm}$ mesh to separate FPOM and the coarse material was added back to the twigs or leaves categories. We washed all samples to remove inorganic material. The samples were dried to constant weight at $60^{\circ} \mathrm{C}$.

We estimated periphyton (biofilm) mass and algal content as follows: At each site we chose 10 near horizontal rock surfaces and 10 near vertical rock surfaces and sampled each twice using an algae sampler. The algae sampler consisted of a kitchen sink plunger with a brush attached to the handle inside the plunger cup and a $60-\mathrm{mL}$ plastic syringe inserted into the side of the plunger (cf Loeb 1981). We collected samples by pressing the plunger firmly to the substrate, scrubbing the substrate with the brush, and filling the syringe with the contents of the plunger cup. The volume of the syringe was larger than that of the plunger, so all of the material suspended by scrubbing was retrieved. The plunger sampled $40.6 \mathrm{~cm}^{2}$ of the rock surface. We read the turbidity and fluorescence of the sample in a hand-held fluorimeter (Aquafluor 8000, Turner Instruments, Sunnyvale, CA, USA) and converted the turbidity to dry mass and fluorescence to chlorophyll using known relationships. Based on previous results we assumed that $39 \%$ of the dry mass was ash-free dry mass (AFDM). We converted chlorophyll mass to algal mass by multiplying by 100 (Napolitano 1994 gives values between 80 and 126 for this conversion).

Samples for stable isotope analysis were collected in early February 2002. All sites were within 30 minutes walking distance of the field laboratory. This allowed us to collect samples and then quickly start to work on sample processing. The samples for each taxon were made from a homogenized powder of different numbers of individuals due to the differences in size and weight of the different fauna collected (Table 3.). We took more than one sample of Cloeodes at Mãe D'água to test differences of isotopic signatures between individuals that were left in water to eliminate gut contents and samples in which the individuals had their guts removed by dissection (see Jardine et al. 2005). To detect a possible ontogenetic shift in isotopic signature of Macrobrachium olfersi (shrimp), samples from three size classes: small $(<2.0 \mathrm{~cm})$, medium $(2.5-4.5 \mathrm{~cm})$ and large $(>4.5 \mathrm{~cm})$ body length were analysed.

We collected in-stream particulate organic matter of obviously terrestrial origin by hand and separated it by washing with distilled water through soil sieves, into fine particulate organic matter, FPOM $(0.25-1 \mathrm{~mm})$ and coarse particulate organic matter, CPOM (1-4 mm). Benthic primary producers such as filamentous algae, moss and the aquatic angiosperm (Podostemaceae) were also sampled by hand. Biofilm was scrubbed off with an algae sampler (described above) and also sampled by dragging a small plastic bag across the rock surface. To separate the microalgal fraction from the rest of the biofilm, the collected material was centrifuged at different speeds. We observed that the less dense material in the supernatant contained a higher density of algae than the precipitate, which appeared to be mainly FPOM. We removed the supernatant and repeated the procedure until we obtained a fraction that appeared predominantly of algal origin on microscopic inspection. 
We sampled aquatic macroinvertebrates and fishes at all the sites with a variety of nets and traps. The aquatic insects were placed in filtered water for several hours in order for them to void part of their intestinal contents before they were processed whole. The fish and shrimps were dissected and muscle tissue taken for processing; exoskeleton, scales and internal organs were not included in the material for analysis. We dissected specimens of the insects and crustaceans under stereomicroscope to obtain gut contents for microscopic examination.

All samples were oven dried at $60^{\circ} \mathrm{C}$ for $24 \mathrm{~h}$ and then ground with pestle and mortar. They were analysed in a continuous flow-isotope ratio mass spectrometer (Micromass Isoprime, Manchester, U.K. and EuroVector EA 3000, elemental analyser, Milan, Italy) in dual isotope mode to obtain elemental and isotopic values for carbon $(\mathrm{C})$ and nitrogen $(\mathrm{N})$ of the samples. Isotope ratios are expressed as the relative per mil (\%o) difference between the sample and conventional standards; Pee Dee Belemnite (PDB) for $\delta^{13} \mathrm{C}$ and $\mathrm{N}_{2}$ in air for $\delta^{15} \mathrm{~N}$ as follows: $\delta \mathrm{X}=$ [R sample/ R standard - 1] 1000 (\%), where $\mathrm{X}={ }^{13} \mathrm{C}$ or ${ }^{15} \mathrm{~N}$ and $\mathrm{R}={ }^{13} \mathrm{C} /{ }^{12} \mathrm{C}$ or ${ }^{15} \mathrm{~N} /{ }^{14} \mathrm{~N}$.

We expected that the carbon signatures of consumer organisms would be closely aligned with their source of carbon, with at most $0.8 \%$ enrichment for each trophic level and show 2 to 3\%o enrichment of nitrogen signatures for each trophic level (Peterson \& Fry 1987). We do not present a formal mixing model applied to the data; it was obvious that we were unable to sample the source of algae of several of the consumers, and in these cases a mixing model would give anomalous results.

\section{RESULTS}

All sites were relatively unshaded and open. The uppermost site, Characidium, had $70 \%$ canopy cover as measured by a concave-mirror densiometer, but still registered $64 \%$ of full-sky irradiance during a daily cycle (Table 1). The other sites were less shaded.

Table 1. Characteristics of the sites

\begin{tabular}{|c|c|c|c|c|c|c|}
\hline \multirow{2}{*}{ Site } & \multirow{2}{*}{ Coordinates } & \multirow{2}{*}{$\begin{array}{l}\text { Altitude } \\
\text { (m a.s.1.) }\end{array}$} & \multicolumn{2}{|c|}{ Width (m) } & \multirow{2}{*}{$\begin{array}{c}\text { Canopy } \\
\text { cover } \\
\text { \% canopy }\end{array}$} & \multirow{2}{*}{$\begin{array}{c}\text { Illumination } \\
\% \text { full } \\
\text { sunlight }\end{array}$} \\
\hline & & & total & wetted & & \\
\hline Characidium & $\begin{array}{l}\mathrm{S}^{2} 3^{\circ} 10.933^{\prime} \\
\mathrm{W} 44^{\circ} 12.137^{\prime}\end{array}$ & 82 & 20 & 10 & 69 & 64 \\
\hline Mãe D'água & $\begin{array}{l}\mathrm{S} 23^{\circ} 10.970^{\prime} \\
\mathrm{W}^{\prime} 4^{\circ} 12.077^{\prime}\end{array}$ & 77 & 24 & 18 & 21 & 100 \\
\hline Bagre & $\begin{array}{l}\mathrm{S}_{23}^{\circ} 10.990^{\prime} \\
\mathrm{W} 44^{\circ} 12.041^{\prime}\end{array}$ & 56 & 11 & 11 & 29 & 80 \\
\hline Lambari & $\begin{array}{l}\mathrm{S}_{23}^{\circ} 11.062^{\prime} \\
\mathrm{W} 44^{\circ} 12.040^{\prime}\end{array}$ & 38 & 29 & 12.5 & 36 & 84 \\
\hline
\end{tabular}

As expected, allochthonous carbon in the form of litter dominated the carbon stocks of each site (Table 2). CPOM dry mass standing crop ranged in the different sites from 45.9 to $146 \mathrm{~g} / \mathrm{m}^{2}$, with an overall mean of $66.1 \mathrm{~g} / \mathrm{m}^{2}$. FPOM averaged $0.67 \mathrm{~g} / \mathrm{m}^{2}$ (Table 2). FPOM filtered from surface water was approximately $0.7 \mathrm{mg} / \mathrm{L}$ (unpublished data, July 2004). The majority of litter was represented by twigs and branches; leaves represented only $23 \%$ of the total. We found more litter retained between rocks and near 
the littoral zone, than in sandy pools, for all classes. The litter collected in pools was, however, much more processed.

Table 2. Mass of carbon stocks in Córrego da Andorinha.

\begin{tabular}{|c|c|c|c|c|c|c|c|c|c|}
\hline \multirow[b]{2}{*}{ Site } & \multicolumn{3}{|c|}{ Mass of litter $\mathrm{g} / \mathrm{m}^{2}(\mathrm{n}=4)$} & \multicolumn{2}{|c|}{$\begin{array}{c}\text { AFDM of } \\
\text { periphyton } \mathrm{g} / \mathrm{m}^{2} \\
(\mathrm{n}=40)\end{array}$} & \multicolumn{2}{|c|}{$\begin{array}{l}\text { Mass of algae in } \\
\text { periphyton } \mathrm{g} / \mathrm{m}^{2} \\
\qquad(\mathrm{n}=40)\end{array}$} & \multirow[t]{2}{*}{$\begin{array}{l}\% \text { algae in } \\
\text { periphyton }\end{array}$} & \multirow[t]{2}{*}{$\begin{array}{c}\% \text { algae in total } \\
\text { biomass }\end{array}$} \\
\hline & & mean & s.e. & mean & s.e. & mean & s.e. & & \\
\hline \multirow{5}{*}{ Characidium } & leaves & 18.9 & 4.3 & \multirow{5}{*}{0.98} & \multirow{5}{*}{0.12} & \multirow{5}{*}{0.166} & \multirow{5}{*}{0.020} & \multirow{5}{*}{$17.0 \%$} & \multirow{5}{*}{$0.14 \%$} \\
\hline & twigs & 12.9 & 11.7 & & & & & & \\
\hline & branches & 84.2 & 38.9 & & & & & & \\
\hline & FPOM & 0.5 & 0.3 & & & & & & \\
\hline & total & 116.5 & 55.2 & & & & & & \\
\hline \multirow{5}{*}{ Mãe D'água } & leaves & 4.9 & 1.0 & \multirow{5}{*}{1.34} & \multirow{5}{*}{0.16} & \multirow{5}{*}{0.053} & \multirow{5}{*}{0.006} & \multirow{5}{*}{$3.9 \%$} & \multirow{5}{*}{$0.12 \%$} \\
\hline & twigs & 5.2 & 3.1 & & & & & & \\
\hline & branches & 33.7 & 26.8 & & & & & & \\
\hline & FPOM & 0.7 & 0.3 & & & & & & \\
\hline & total & 44.5 & 31.3 & & & & & & \\
\hline \multirow{5}{*}{ Bagre } & leaves & 18.4 & 6.9 & \multirow{5}{*}{5.23} & \multirow{5}{*}{0.39} & \multirow{5}{*}{0.486} & \multirow{5}{*}{0.041} & \multirow{5}{*}{$9.3 \%$} & \multirow{5}{*}{$0.83 \%$} \\
\hline & twigs & 19.6 & 6.7 & & & & & & \\
\hline & branches & 15.5 & 6.9 & & & & & & \\
\hline & FPOM & 0.7 & 0.2 & & & & & & \\
\hline & total & 54.2 & 20.7 & & & & & & \\
\hline \multirow{5}{*}{ Lambari } & leaves & 9.1 & 3.7 & \multirow{5}{*}{4.94} & \multirow{5}{*}{0.33} & \multirow{5}{*}{0.235} & \multirow{5}{*}{0.018} & \multirow{5}{*}{$4.8 \%$} & \\
\hline & twigs & 42.9 & 11.3 & & & & & & \\
\hline & branches & 59.0 & 59.0 & & & & & & $0.20 \%$ \\
\hline & FPOM & 0.8 & 0.5 & & & & & & \\
\hline & total & 111.8 & 74.4 & & & & & & \\
\hline
\end{tabular}

Periphyton sampled from rocks ranged from 0.98 to $5.23 \mathrm{~g} / \mathrm{m}^{2}$ (Table 2.). It was higher in the two sites below the waterfall which have active predatory fish compared to the sites above the waterfall. The estimated algal content of the periphyton varied between $4 \%$ and $17 \%$, and the total algae was less than $1 \%$ of the total biomass at all sites.

All sources of particulate organic matter (POM) had very similar $\delta^{13} \mathrm{C}$ values of approximately $-30 \%$ o. $\delta^{15} \mathrm{~N}$ values of fine particulate matter (FPOM) ranged from 1.2 to $2.2 \%$ and the single sample of coarse particulate matter (CPOM) had a value of $0.7 \%$ (Table 3, Fig. 1).

We obtained algae from all but the uppermost shaded site, where the biofilm was sparse and we found no filamentous forms. Algal $\delta^{13} \mathrm{C}$ values varied between -19 and $-25 \%$; and $\delta^{15} \mathrm{~N}$ between 1.4 and 2.5\% (Table 3, Fig. 1). The carbon of the single microalgal sample from the lowest site was distinctly more ${ }^{13} \mathrm{C}$-depleted $(-25 \%)$ than the samples from upstream (average $-21 \%$ ). The carbon of the single sample of filamentous algae was distinctly more depleted $(-25 \%)$ than that of the microalgae of the same site $(-21 \%)$.

The unidentified species of Podostemaceae and moss were found at only the Mãe D'água site. The Podostemaceae had a signature close to the microalgae of the site while the aquatic moss was more similar to terrestrial plant material. 
TABLE 3. Carbon and nitrogen isotope values for consumers and carbon sources. The descriptions of trophic habits are based on literature and gut contents, not on stable isotope analysis. FPOM is fine particulate organic matter; CPOM is coarse particulate organic matter. $N^{\circ}=$ Approximate number of individuals in the sample.

\begin{tabular}{|c|c|c|c|c|}
\hline $\begin{array}{l}\text { Organism or } \\
\text { carbon source }\end{array}$ & Description & $\delta^{13} \mathrm{C}$ & $\delta^{15} \mathrm{~N}$ & $\mathrm{~N}^{\mathrm{o}}$ \\
\hline \multicolumn{5}{|c|}{ Characidium site (highest altitude, $69 \%$ canopy cover) } \\
\hline \multirow[t]{2}{*}{ Cloeodes sp. } & $\begin{array}{l}\text { Baetid mayfly, } \\
\text { generalist }\end{array}$ & & & \\
\hline & grazer & -22.2 & 3.3 & 40 \\
\hline \multirow[t]{2}{*}{$\begin{array}{l}\text { Potimirim } \\
\text { glabra }\end{array}$} & $\begin{array}{l}\text { Atyid shrimp, } \\
\text { sweeping, } \\
\text { collecting }\end{array}$ & & & \\
\hline & omnivore & -23.1 & 6.6 & 10 \\
\hline \multirow{2}{*}{$\begin{array}{l}\text { Characidium } \\
\text { japuhybense }\end{array}$} & $\begin{array}{l}\text { Crenuchid fish, } \\
\text { benthic }\end{array}$ & & & \\
\hline & predator & -22.2 & 8.2 & 3 \\
\hline FPOM & $\begin{array}{l}\text { Separated from } \\
\text { biofilm }\end{array}$ & -29.9 & 1.6 & \\
\hline
\end{tabular}

Mãe D’água site (immediately above waterfall, 21\% canopy cover)

\begin{tabular}{|c|c|c|c|c|}
\hline Cloeodes sp. & $\begin{array}{l}\text { As above } \\
\text { (without guts) }\end{array}$ & -19.4 & 2.8 & 40 \\
\hline Cloeodes sp. & $\begin{array}{l}\text { As above (with } \\
\text { guts) }\end{array}$ & -19.1 & 4.7 & 40 \\
\hline Gripopteryx sp. & $\begin{array}{l}\text { Gripopterygid } \\
\text { stonefly, algal } \\
\text { grazer } \\
\text { Hydropsychid } \\
\text { caddisfly, }\end{array}$ & -22.4 & 3.2 & 10 \\
\hline Smicridea sp. & filterer & -21.8 & 3.3 & 20 \\
\hline $\begin{array}{l}\text { Potimirim } \\
\text { glabra }\end{array}$ & As above & -21.4 & 7.3 & 10 \\
\hline Microalgae & $\begin{array}{l}\text { Scraped from } \\
\text { hard surface in } \\
\text { fast current }\end{array}$ & -21.3 & 2.3 & - \\
\hline $\begin{array}{l}\text { Filamentous } \\
\text { algae }\end{array}$ & $\begin{array}{l}\text { Picked off } \\
\text { bedrock in fast } \\
\text { current }\end{array}$ & -25.1 & 1.4 & - \\
\hline Podostemaceae & $\begin{array}{l}\text { Angiosperm, } \\
\text { fast current }\end{array}$ & -21.2 & 2.4 & - \\
\hline Moss & $\begin{array}{l}\text { Bryophyte, fast } \\
\text { current }\end{array}$ & -30.7 & 2.6 & - \\
\hline
\end{tabular}




$\begin{array}{lllll} & \begin{array}{l}\text { Leaves and } \\ \text { coarse litter }\end{array} & & \\ \text { CPOM } & \text { from stream } & -30 & 0.7\end{array}$

Bagre site (immediately below waterfall, 30\% canopy cover)

\begin{tabular}{|c|c|c|c|}
\hline Cloeodes sp. & As above & -13.4 & 2.6 \\
\hline $\begin{array}{l}\text { M. olfersi (large } \\
\text { size) }\end{array}$ & Palaemonid & -20.2 & 8.1 \\
\hline $\begin{array}{l}\text { M. olfersi } \\
\text { (medium size) }\end{array}$ & $\begin{array}{l}\text { shrimp, picking } \\
\text { collector, }\end{array}$ & -18.5 & 7.1 \\
\hline $\begin{array}{l}\text { M. olfersi (small } \\
\text { size) }\end{array}$ & omnivore & -17.1 & 7.5 \\
\hline $\begin{array}{l}\text { M. heterochirus } \\
\text { (very large size) }\end{array}$ & $\begin{array}{l}\text { Similar to } M \text {. } \\
\text { olfersi }\end{array}$ & -24.8 & 7.7 \\
\hline $\begin{array}{l}\text { Rhamdioglanis } \\
\text { transfasciatus }\end{array}$ & $\begin{array}{l}\text { Heptapterid } \\
\text { catfish, benthic } \\
\text { predator }\end{array}$ & -19.1 & 9.3 \\
\hline Microalgae & $\begin{array}{l}\text { Separated from } \\
\text { biofilm }\end{array}$ & -19 & 1.4 \\
\hline Microalgae & $\begin{array}{l}\text { Separated from } \\
\text { hard substrate }\end{array}$ & -21.6 & 2.3 \\
\hline FPOM & $\begin{array}{l}\text { Separated from } \\
\text { biofilm }\end{array}$ & -29.4 & 2 \\
\hline
\end{tabular}

Lambari site (lowest altitude, 37\% canopy cover)

\begin{tabular}{|c|c|c|c|}
\hline Cloeodes sp. & As above & -15.6 & 1.9 \\
\hline $\begin{array}{l}\text { M. olfersi (large } \\
\text { size) }\end{array}$ & & -23.5 & 7.7 \\
\hline $\begin{array}{l}\text { M. olfersi (large } \\
\text { size gravid) }\end{array}$ & ove & -18.2 & 6.9 \\
\hline $\begin{array}{l}\text { M. olfersi } \\
\text { (medium size) }\end{array}$ & & -17.1 & 6.9 \\
\hline $\begin{array}{l}\text { M. olfersi (small } \\
\text { size) }\end{array}$ & & -19.6 & 7.3 \\
\hline Eleotris pisonis & $\begin{array}{l}\text { Eleotrid fish, } \\
\text { benthic sit and } \\
\text { wait predator }\end{array}$ & -17.5 & 7.6 \\
\hline $\begin{array}{l}\text { Bryconamericus } \\
\text { microcephalus }\end{array}$ & $\begin{array}{l}\text { Characid fish, } \\
\text { swimming } \\
\text { predator, } \\
\text { omnivore }\end{array}$ & -20.8 & 8.1 \\
\hline
\end{tabular}




$\begin{array}{lllll}\begin{array}{l}\text { Phalloceros } \\ \text { caudimaculatus }\end{array} & \begin{array}{l}\text { Poeciliid fish, } \\ \text { swimming } \\ \text { predator, } \\ \text { omnivore }\end{array} & -23.5 & 7.5 & 7 \\ \text { Microalgae } & \begin{array}{l}\text { Separated from } \\ \text { biofilm }\end{array} & -25.6 & 2.5 & - \\ \text { FPOM } & \begin{array}{l}\text { Separated from } \\ \text { biofilm }\end{array} & -29.6 & 2.2 & -\end{array}$

Other sites

\begin{tabular}{llccc}
$\begin{array}{l}\text { M.. olfersi } \\
\text { (medium size) }\end{array}$ & As above & -22.2 & 6.5 & 15 \\
$\begin{array}{l}\text { M. olfersi (all } \\
\text { sites mixture) }\end{array}$ & -19.6 & 7.3 & 5 \\
$\begin{array}{l}\text { M. heterochirus } \\
\text { (very large size) }\end{array}$ & $\begin{array}{l}\text { Similar to } M . \\
\text { olfersi }\end{array}$ & -24.8 & 7.7 & 1 \\
$\begin{array}{l}\text { M. carcinus } \\
\text { (very large size) }\end{array}$ & $\begin{array}{l}\text { Similar to } M . \\
\text { olfersi }\end{array}$ & -24 & 7.6 & 1 \\
\hline
\end{tabular}

The baetid mayfly Cloeodes was found at each site, generally on exposed rocks or vertical faces in pools and places with low to medium water velocity. Its stable isotope signatures were quite variable (Table 3, Fig. 1) ranging from $-13.4 \%$ o to $-22.2 \%$ o and $1.9 \%$ to $4.7 \%$, for $\delta^{13} \mathrm{C}$ and $\delta^{15} \mathrm{~N}$, respectively. Its $\delta^{13} \mathrm{C}$ in the lower two sites appeared more enriched in ${ }^{13} \mathrm{C}$ than in the upper two sites. At each site Cloeodes appeared more enriched in ${ }^{13} \mathrm{C}$ than the microalgae of the site. The samples with and without guts were not distinctly different.

We analyzed two other, contrasting, feeding groups of insects: Gripopteryx (stonefly), a selective grazer, and Smicridea (caddisfly) which filters with a silk net that it constructs on the surface of rocks in fast current. Both organisms had $\delta^{13} \mathrm{C}$ values aligned with those of the microalgal samples (Table 3, Fig. 1).

The atyid shrimp, Potimirim glabra, apparently ingests FPOM and algae, which it gathers with its specialized chelae. Its position according to its stable isotope signature was that of a secondary consumer aligned with algae (Table 3, Fig. 1). The palaemonid shrimp, Macrobrachium olfersi was collected from the two lower sites and from low-altitude sites in a neighbouring stream. Its stomach contents were predominantly of particulate organic matter, which is in general coarser than that of Potimirim, plus insect parts and some algae (TPM personal observation). Its stable isotope signature, however, placed the species as a secondary consumer with a carbon source somewhat more enriched than that of the sampled algae. The largest size of $M$. olfersi appeared to have more depleted $\delta^{13} \mathrm{C}$ values compared to the medium and small sizes. The values for $\delta^{15} \mathrm{~N}$ did not vary more than $1 \%$ o between body sizes and showed no obvious pattern. The other Macrobrachium species also appeared to be secondary consumers, but with somewhat less dependence on microalgae (Table 3, Fig. 1).

All 5 species of fish had enriched $\delta^{15} \mathrm{~N}$ signatures indicating secondary or higher trophic position (Table 3, Fig. 1). Their $\delta{ }^{13} \mathrm{C}$ values varied between $-23.5 \%$ o 


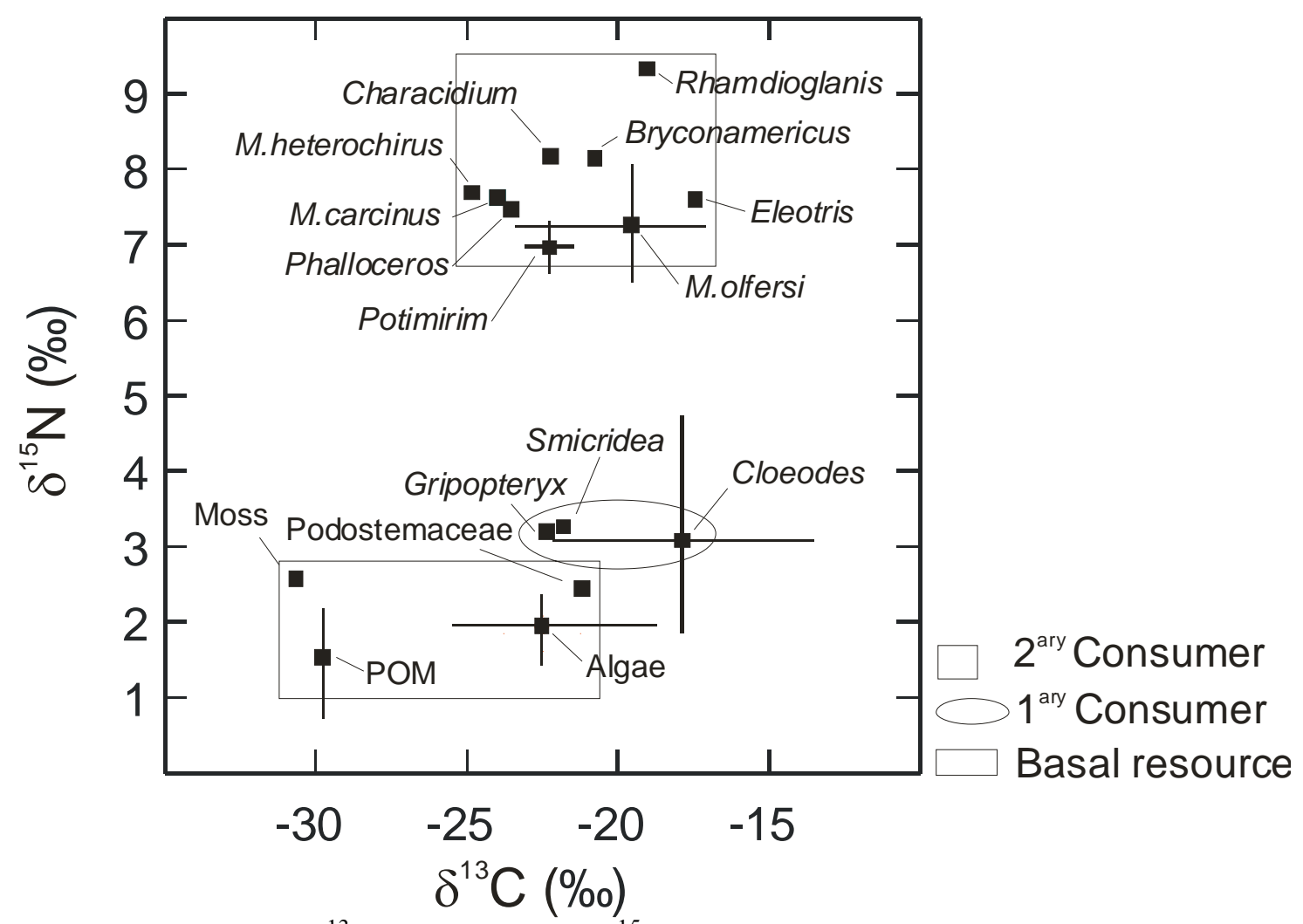

FIGURE 1. Carbon $\left(\delta^{13} \mathrm{C}\right)$ and nitrogen $\left(\delta^{15} \mathrm{~N}\right)$ signatures of basal resources and consumers of all sites. Points are means \pm range. Points without bars are a single sample. $\mathrm{POM}=$ particulate organic matter (FPOM and CPOM combined).

(Phalloceros caudimaculatus) and -17.5\% (Eleotris pisonis), which placed them as having algae as their ultimate food source.

\section{DISCUSSION}

Although the forest is well developed at all sites, it provides little shade due to the width of the stream (Table 1) and instream primary production is probably not light limited. As expected, allochthonous material was overwhelmingly more abundant than in-stream sources (Table 2). The total litter standing crop dry mass was similar to that reported in temperate streams and in Hawaii (Learned 2000). However, we found a higher percentage of twigs and branches compared to leaves which is opposite to what is commonly described in the literature. There was a visible difference of litter standing crop between pool and riffles. Spates occur frequently in the stream, and it appeared that coarse material was carried out of pools and retained between rocks or swept onto the banks above base flow level. According to Webster \& Meyer (1997), patterns of retention, transport and processing can be affected by discharge. Learned (2000) also pointed out that biological processing of the litter may be reduced by short retention time in streams in Hawaii. However, measurements of leaf processing in Córrego da Andorinha and Rio Barra Pequena showed substantial breakdown; leaf mass was reduced to $28 \%$ of original mass in 32 days (Moulton \& Magalhães 2003). We assume that biological decomposition of litter is active in our stream.

The quantity of periphyton was greater at the two lower sites compared to the two upper sites as we expected from our inference that fish predation inhibits shrimp grazing (Souza et al. 2001). The range of periphyton density was similar to those of 
other tropical streams (e.g. March et al. 2002) and unenriched streams (Biggs 1996). We calculated the expected biomass of algae in the periphyton based on an average value of AFDM to chlorophyll (100) seen in quantitative studies of periphyton composition (e.g. Napolitano 1995) and experimental studies of periphyton (e.g. Hill et al. 1995). This extrapolated to a relatively low percentage of algae in the periphyton (4 to $17 \%$ ). This is low compared to many experimental studies in temperate regions (e.g. Hill et al. 1995), but is similar to values found in tropical streams (March et al. 2002) and in unenriched sites in New Zealand (Biggs 1996). Previous studies have remarked on this low proportion of algal biomass in the periphyton at the Mãe D'água site (Moulton et al. 2004) and upstream of the Characidium site (Souza \& Moulton 2005).

We present data of the stocks of organic material knowing that the rates of production are critical for the interpretation of material flow (e.g. McIntire \& Colby 1978). The dynamics of carbon flow are beyond the scope of the present study, but we can note that the rate of production of periphyton biomass at Mãe D'água was approximately $1 \mathrm{~g} / \mathrm{m}^{2} /$ day in the absence of grazing (Moulton et al. 2004).

We did not determine the mass of moss and Podostemaceae. Moss occurred in small quantities at all sites and is common at some places in Córrego da Andorinha that we did not sample. Podostemaceae was common on the sloping rockface at Mãe D'água, but was apparently absent at the other sites. The lack of quantitative sampling of these components probably does not affect our conclusions about the major sources of carbon in the stream food web.

The stable isotope signatures of the basal resources were well differentiated, which allowed us to analyze trophic relationships. As expected, the carbon from the surrounding forest had a relatively uniform $\delta^{13} \mathrm{C}$ of $-30 \%$, typical of $\mathrm{C} 3$ vegetation (Peterson \& Fry 1987). Microalgae separated from biofilm or scraped from hard substrate and filamentous algae had distinctly more enriched $\delta^{13} \mathrm{C}$ values, from $-25 \%$ o to $-19 \%$ (Table 3). All primary consumers and higher trophic levels that we sampled had $\delta^{13} \mathrm{C}$ signatures strongly aligned with microalgae; many samples were more enriched than the level we expected for assimilation of microalgae.

At least part of the anomalously enriched signatures can be explained by the difficulty of isolating the microalgae that the animals feed on. Ephemeropterans have been shown to incorporate specific components of the periphyton on which they feed (Mulholland et al. 2000, Rezanka \& Hershey 2003). We think this is a likely explanation for results of Cloeodes, which from its gut contents appeared to ingest periphyton without discriminating among the components, but apparently assimilated a ${ }^{13} \mathrm{C}$-enriched source of carbon. Moreover, the source appears to be somewhat more enriched than the microalgae that we separated from the periphyton. We think it likely that we were not able to completely isolate the algae that Cloeodes assimilates. We attempted to do this by centrifuging the periphyton sample, but it is probable that some allochthonous material remained in the algal sample. The results of the samples with and without guts of Cloeodes at Mãe D'água site did not confirm our hypothesis that the less depleted $\delta^{15} \mathrm{~N}$ and $\delta^{13} \mathrm{C}$ signature of the terrestrial material present in the insect guts would mask the values of the food source that was being assimilated. A similar observation has been made for a variety of other benthic insects (Jardine et al. 2005).

A potential source of variation in the $\delta^{13} \mathrm{C}$ signature of algae was the current velocity of the position in which they were sampled - more depleted signatures are expected in faster-flowing conditions (Finlay et al. 1999, Finlay 2004). We sampled principally from medium to fast current which might have led to depleted signatures of the algae compared to the algae potentially grazed in pools. Cloeodes, the shrimps and the fish tend to inhabit pools and places of lower current; Gripopteryx and Smicridea 
are found in riffles. Periphyton was very sparse in the microhabitats that were heavily grazed by Cloeodes and Potimirim and this made for practical difficulties in sampling it.

Finlay (2004) found more depleted $\delta^{13} \mathrm{C}$ values in microalgae of smaller, forested streams compared to downstream productive sites. In contrast to this, we observed that the lowest site had a more depleted signature compared to the upstream sites. On the other hand, the grazer, Cloeodes showed a trend of increasingly enriched $\delta^{13} \mathrm{C}$ signature from the highest to the lowest site (Table 3.) and apparently associated with the discontinuity caused by the waterfall between the upper and lower sites. Some studies have used known grazers to track the signatures of their algal diet, due to the difficulty of separating pure microalgae in sufficient quantities for analysis (e.g. Finlay et al. 1999). It is possible that trend observed in the $\delta^{13} \mathrm{C}$ signature of Cloeodes is a more accurate description of the trend in the microalgae than that of our attempts in measuring the algae directly.

Plants other than algae are unlikely to have contributed to the observed carbon isotope signatures of the fauna. The unidentified species of Podostemaceae had a $\delta^{13} \mathrm{C}$ signature close to that of microalgae, but it is unlikely to be an important source for consumers, because of its rarity and distribution restricted to fast-flowing current. Consumers were consistently too $\delta{ }^{13} \mathrm{C}$ enriched to have derived a significant part of the diet from terrestrial (C3) sources. Plants with $\mathrm{C} 4$ metabolism are a common enriched source in tropical systems (Bunn et al. 1997, Clapcott \& Bunn 2003, Hamilton et al. 1992), but we consider C4 plants as an unlikely source to explain the observed pattern. There were no obvious grasses or other known $\mathrm{C} 4$ plants in the surrounding forest vegetation, and we observed none in the material that we sieved.

The $\delta{ }^{15} \mathrm{~N}$ signatures present anomalies for some putative primary and secondary consumers. The herbivorous Gripopteryx and Smicridea were only 1 to $2 \%$ more enriched than their potential algal food, which was lower than the 2 to $5 \%$ o expected for one step in the food chain (Peterson \& Fry 1987). On the other hand, secondary consumers (fishes and shrimps) were 4 to $6 \%$ more enriched than the primary consumers, and thus more enriched than expected for predators of the primary consumers. They possibly prey mainly on organisms more enriched in $\delta^{15} \mathrm{~N}$ than the insects we sampled. Fishes and shrimps were, however, in the position expected for secondary consumers in a food chain based on algae.

The signature of the stonefly Gripopteryx was as expected for an algal herbivore (Table 3, Fig. 1), and this agrees with our observation that it can graze algae. Albariño \& Villanueva (2002) have observed other species of Gripoterygidae to have a specialist algal diet. On the other hand, we have observed that the gut contents of the filtering trichopteran, Smicridea, contain predominantly fine particulate organic matter and some microalgae. The signature of Smicridea suggests that it is an algal herbivore, and this implies that it assimilates a small proportion of the material that it ingests.

The species of Macrobrachium are described in the literature as omnivores; they ingest detritus, filamentous algae and animal prey by picking them with chelae.

Potimirim also ingests detritus by sweeping with its modified, setaceous, chelae (Fryer 1997). We observed that their gut contents were primarily of FPOM. Macrobrachium tended to have larger pieces of organic material and some animal parts compared to the finer particles in the guts of Potimirim. The $\delta^{13} \mathrm{C}$ values of both genera indicated, however, that they assimilate primarily material of microalgal origin, and the $\delta^{15} \mathrm{~N}$ values indicated secondary consumers. March \& Pringle (2003) noted a similar pattern in species of three shrimp genera (Atya, Macrobrachium and Xiphocaris) in a stream in Puerto Rico, although in their case the shrimps generally had some contribution of allochthonous sources in their signatures. They also observed relatively enriched $\delta^{15} \mathrm{~N}$ 
signatures, which implied that the shrimps were secondary consumers. Mantel et al. (2004) observed a variety of animal prey in the diet of Macrobrachium hainanense, including baetid ephemeropterans and chironomids, which corroborated an enriched $\delta^{15} \mathrm{~N}$ signature. Yam \& Dudgeon (2005) observed a predominantly algal-based signature in omnivorous atyid shrimps Caridina spp.

Manipulative experiments have shown that $M$. olfersi has a strong negative effect on Cloeodes at the site Mãe D'água (Silveira \& Moulton 2000, Krsulović 2004, Moulton et al. 2004). This is consistent with its $\delta^{13} \mathrm{C}$ and $\delta^{15} \mathrm{~N}$ signature as a predator of prey based on microalgae. We have not, however, commonly observed remains of Cloeodes or other animals in the guts of M. olfersi. In contrast, Potimirim removed organic and inorganic benthic material in an experiment approximately $500 \mathrm{~m}$ upstream from the Characidium site (Souza \& Moulton 2005), in a manner similar to that observed with other atyid shrimps (Pringle \& Blake 1994, March et al. 2001, Yam \& Dudgeon 2005) and consistent with their role in organic matter processing (Covich, 1988, Crowl et al. 2001). It had a positive interaction with baetid ephemeropterans and no observable effect on chironomid larvae. This evidence, coupled with the preponderance of FPOM and lack of observable animal remains in its guts, makes its isotopic signature puzzling.

We have preliminary data showing that large M. olfersi have more depleted $\delta^{13} \mathrm{C}$ signatures, as do large individuals of the other Macrobrachium species (Table 3, Fig. 1). This may indicate that larger individuals incorporate some carbon derived from allochthonous sources, although the corresponding $\delta^{15} \mathrm{~N}$ values do not indicate direct detritivory.

A diet study of Bryconamericus microcephalus in Córrego da Andorinha found that the fish consumed insects principally from allochthonous sources, in contrast to data from the literature that indicated it as an omnivore and partially algivorous (Rezende \& Mazzoni 2003). Our collection from site Lambari was approximately $200 \mathrm{~m}$ upstream from this study; the stable isotope signature indicated Bryconamericus as a secondary consumer of sources based on algae and not on allochthonous sources. Possibly at least some of the incongruence of our results and those of Rezende \& Mazzoni (2003) and of other literature was caused by variations among sites, but we can note that the observed alimentary canal contents of most of the fauna of our study do not match the trophic status indicated by stable isotope analysis. In the case of Eleotris we suspect that the enriched signature comes from an estuarine source downstream, since this species is known to move between brackish and fresh water (Perrone \& Vieira 1991). Characidium japuhybense is described as an insectivore (Sabino \& Castro 1990), and this is supported by stable isotopes. Phalloceros is an active, swimming, feeder, and its gut contents indicate an omnivorous diet (Tosta, personal communication). It probably ingests periphyton, but its isotopic signature suggests that it assimilates animal prey based on algae.

Our sampling sites were not very shaded, and we could expect that algal production was not light limited, even at the uppermost site. We cannot contrast our results with patterns found in smaller, lower-order forest streams where algal production is limited (e.g. Salas \& Dudgeon 2001, Mantel et al. 2004). But we can note that all of the consumers that we sampled were apparently predominantly assimilating carbon derived from algae. Even the organisms that ingested predominantly allochthonous organic matter (the two genera of shrimps, filtering caddisfly and Cloeodes) did not apparently assimilate this material.

Our results are from a single point in time, in summer in the rainy season. We can expect that there could be seasonal variations in isotope signatures, but because the 
locality is not strongly seasonal in temperature, sunlight and rainfall, this variation would be much less than that observed, for example, in California (Finlay 2004).

We conclude that our study adds to the growing evidence that algae, and particularly microalgae, are disproportionately represented as food sources in small tropical stream food webs compared to their biomass relative to allochthonous matter. We must not assume that because a food source is common that it should predominate in the food web, and we cannot rely on food intake and gut contents to indicate the trophic status of consumers.

\section{ACKNOWLEDGEMENTS}

This research was undertaken during study leave at CRL, Griffith University. EFB, TPM and MLS thank their hosts and particularly Rene Diocares for his expertise with the isotope analysis. Steve Hamilton provided invaluable assistance in technical and theoretical matters. Jonathan Grey gave us helpful comments on the manuscript, as did two anonymous referees of an earlier version. The field work was carried out at Centro de Estudos Ambientais e Desenvolvimento Sustentável (CEADS), Ilha Grande, a campus of UERJ. We thank the staff there and our colleagues Kenny Tanisaki-Fonseca, Roberto Silveira, Felipe Krsulović, Márcio Miranda, Taldi Walters and others for assistance in the field and laboratory. We thank Rosana Mazzoni and her students for the identification of the fish, Roberto Silveira for the shrimps, Elidiomar Ribeiro da Silva for the mayfly, Ana Huamantinco for the caddisfly and Martina Olifiers for the stonefly.

\section{REFERENCES}

Albariño, R., AND V. D.VillanUeVA. 2003. Feeding plasticity and growth of two plecopteran larvae in a low order Andean stream. In E. Gaino (Ed.). Research Update on Ephemeroptera \& Plecoptera, pp. 31-38. University of Perugia, Perugia, Italy.

BARBEE, N.C. 2005. Grazing insects reduce algal biomass in a neotropical stream. Hydrobiologia. 532: 153-165.

Biggs, B. J. F. 1996. Patterns in benthic algae of streams. In Stevenson, R. J., M. L. Bothwell and R. L. Lowe (Eds.), Algal ecology: freshwater benthic ecosystems, pp 31-56. Academic Press, San Diego.

BunN, S. E., AND P. I. BoON. 1993. What sources of organic carbon drive food webs in billabongs? A study based on stable isotope analysis. Oecologia 96: 85-94.

---, DAVIES, P. M., AND D. M. KellawAY. 1997. Contributions of sugar cane and invasive pasture grass to the aquatic food web of a tropical lowland stream. Mar. Freshwater Res. 48: 173-179.

---, Mosisch, T. D., AND P. M. DAVIES.1999a. Temperature and light. In Lovett, S. \& Price, P. (eds.). Riparian land management technical guidelines volume one: principles of sound management, pp. 17-24.

---, DAVIES, P. M., AND T. D. Mosisch. 1999b. Ecosystem measures of river health and their response to riparian and catchment degradation. Freshwater Biol. 41: 333345 .

Clapcott, J. E., AND S. E. Bunn. 2003. Can C4 plants contribute to the aquatic food webs of subtropical streams? Freshwater Biol. 48: 1105-1116.

Crowl, T. A., W. H. MCDowell, A. P. COVICH, AND S. L. JohnSON. 2001. Freshwater shrimp effects on detrital processing and nutrients in a tropical headwater stream. Ecology 82: 775-783. 
Covich, A. P. 1988. Geographical and historical comparisons of neotropical streams: biotic diversity and detrital processing in highly variable habitats. J. N. Am. Benthol. Soc. 14: 174-182.

Cummins, K. W., R. C. Petersen, F. O. Howard, J. C. Wuycheck, And V. I. Holf. 1973. The utilization of leaf litter by stream detritivores. Ecology 54: 336-345.

Douglas, M. M., S. E. BunN, AND P. M. DAVIES. 2005. River and wetland food webs in Australia's wet-dry tropics: general principles and implications for management. Mar. Freshwater Res. 56: 329-342.

DudGEON, D., AND K. K. Y. WU. 1999. Leaf litter in a tropical stream: food or substrate for macroinvertebrates? Archiv für Hydrobiologie 146: 65-82.

Finlay, J. C., M. E. POWER, AND G. CABANA.1999. Effects of water velocity on algal carbon isotope ratios: Implications for river food web studies. Limnol. Oceanogr. 44: 1198-1203.

---, 2004. Patterns and controls of lotic algal stable carbon isotope ratios. Limnol. Oceanogr. 49: 850-861.

FisheR, S. G., AND G. E. LiKENS. 1973. Energy flow in Bear Brook, New Hampshire: an integrative approach to stream ecosystem metabolism. Ecol. Monogr. 43: 421439.

FLECKER, A.S. 1996. Ecosystem engineering by a dominant detritivore in a diverse tropical stream. Ecology 77:1845-1854.

FRYER, G. 1977. Studies on the functional morphology and ecology of the atyid prawns of Dominica. Philos. Trans. R. Soc. Lond. Ser. B- Biol. Sci. 25: 277 (952): 57-128.

ForsberG, B. R., C. A. R. M. Araujo-Lima, L. A. Martinelli, R. L. Victoria, And J. A. BoNASSI. 1993. Autotrophic carbon sources for fish of the Central Amazon. Ecology 74: 643-652.

GrAÇA, M. A. S. 1993. Patterns and processes in detritus-based stream systems. Limnologica 23: 107-114.

HAASE, R. 1999. Litterfall and nutrient return in seasonally flooded and non-flooded forest of the Pantanal, Mato Grosso, Brazil. Forest Ecol. Mnt. 117: 129-147.

HAMiLton, K. S., M. W. JR. LEWIS, AND J. S. SiPPEL. 1992. Energy source for aquatic animal in the Orinoco River floodplain evidence from stable isotopes. Oecologia 89: 324-330.

HECKY, R. E., AND H. R. HESSLEIN. 1995. Contributions of benthic algae to lake food webs as revealed by stable isotope analyses. J. N. Am. Benthol. Soc. 14: 631-653.

HENRY, R., V. S. UIEDA, A. A. O. AfONSO, AND R. M. KIKUCHI. 1994. Input of allochthonous matter and structure of fauna in a Brazilian headstream. Verh. Internat. Verein. Limnol. 25: 1866-1870.

HiLL, W. R., M. G. RYON, AND E. M. SCHILLING. 1995. Light limitation in a stream ecosystem: responses by primary producers and consumers. Ecology 76: 12971309.

Jardine, T. D., R. A. Curry, K. S. Heard, And R. A. CunjaK. 2005. High fidelity: isotopic relationship between stream invertebrates and their gut contents. J. N. Am. Benthol. Soc. 24: 290-299.

KitTing, L. C., B. Fry AND D. M. Morgan. 1984. Detection of inconspicuous epiphytic algae supporting food webs in seagrass meadows. Oecologia 62: 145149.

KRSUlOVić, F. A. M. 2004. Avaliação de mecanismos de remoção de perifiton por ninfas de Ephemeroptera em um córrego, Ilha Grande, Brasil. Masters dissertation, Universidade do Estado do Rio de Janeiro, Rio de Janeiro, Brasil.

LEARNED, S. T. 2000. Dynamics of coarse riparian detritus in Hawaiian stream 
ecosystem: a comparison of drought and post-drought conditions. J. N. Am. Benthol. Soc. 19: 215-234.

LOEB, S. L. 1981. An in situ method for measuring the primary productivity and standing crop of the epilithic periphyton community in lentic systems. Limnol. and Oceanogr. 26: 394-399.

Mantel, S. K., M. SAlAS AND D. DudgeON. 2004. Food web structure in a tropical Asian forest stream. J. N. Am. Benthol. Soc. 23: 728-755.

Mathuriau, C., And E. Chauvet. 2002. Breakdown of leaf litter in a neotropical stream. J. N. Am. Benthol. Soc. 21: $384-396$.

March, J. G., J. P. Benstead, C. M. Pringle, And M. W. Ruebel. 2001. Linking shrimp assemblages with rates of detrital processing along an elevational gradient in a tropical stream. Can. J. Fish. Aquat. Sci. 58: 470-478.

---, C.M. PRINGLE, M.J. TOWNSEND, AND A.I. WILSON. 2002. Effects of freshwater shrimp assemblages on benthic communities along an altitudinal gradient of a tropical island stream. Freshwater Biology 47: 377-390.

---, AND C.M. PRINGLE. 2003. Food web structure and basal resource utilization along a tropical island stream continuum, Puerto Rico. Biotropica 35: 84-93.

MCINTIRE, D. C., AND COLBY, J. A. 1978. A hierarchical model of lotic ecosystems. Ecol. Monogr. 48: 167-190.

Moulton, T. P., AND S. A. P., MagalhãEs. 2003. Responses of leaf processing to impacts in streams in Atlantic rainforest, Rio de Janeiro, Brazil - A test of the biodiversity-ecosystem functioning relationship? Braz. J. Biol. 63: 87-95.

---, AND M. L. SOUZA. 1998. Comparisons of the benthic community dynamics of a freshwater stream rock-face and the marine intertidal. IV Simpósio de Ecossistemas Brasileiros. 2: 237-243.

---, M. L. SouzA, R. M. L. Silveira, AND F. A. M. Krsulović. 2004. Effects of ephemeropterans and shrimps on periphyton and sediments in a coastal stream (Atlantic forest, Rio de Janeiro, Brazil). J. N. Am. Benthol. Soc. 23: 868-881.

Mulholland, P. J., J. L. Tank, D. M. Sanzone, W. M. Wollheim, B. J. Peterson, J. R.WeBSTER, AND J. L. MEYER. 2000. Food Resources of Stream Macroinvertebrates Determined by Natural-Abundance Stable C and N Isotopes and a N-15 Tracer Addition. J. N. Am. Benthol. Soc. 19: 145-157.

NAPOLITANO, G.E. 1994. The relationship of lipids with light and chlorophyll measurements in freshwater algae and periphyton. J. Phycol. 30:943-950.

Perrone, E. C. AND F. VIERA. 1991. Hábito alimentar de Eleotris pisonis (Teleostei: Eleotridae) na região estuarina do rio Jucu, Espírito Santo, Brasil. Rev. Bras. Biol. 51: 867-872.

Peterson, J. B., AND B. Fry.1987. Stable isotopes in ecosystem studies. Annual Review of Ecology and Systematics 18: 293-320.

Por, F. D., AND R. M. LOPES.1994. The streams of the Atlantic rain forest of Brazil. Verh. Internat. Verein. Limnol. 25: 1871-1875.

Post, D. M. 2002. Using stable isotopes to estimate trophic position: Models, methods, and assumptions. Ecology 83: 703-718.

Pringle, C. M., AND G. A. BlaKe. 1994. Quantitative effects of atyid shrimp (Decapoda: Atyidae) on the depositional environment in a tropical stream: use of electricity for experimental exclusion. Can. J. Fish. Aquat. Sci. 51: 1443-1450.

---, AND T. HAMAZAKI. 1998. The role of omnivory in a neotropical stream: separating diurnal and nocturnal effects. Ecology 79: 269-280.

RESENDE, F. C., AND R. MAZZONI. 2003. Aspectos da alimentação de Bryconamericus microcephalus (Characiformes, Tetragonopteridae) no córrego Andorinha, Ilha 
Grande RJ. Biota Neotropica. v3. (n1). http://www.biotaneotropica.org.br/v3n1 /pt/abstract?short-communication+BN01603012003

---, AND R. MAZZONI. 2005. Seasonal variation in the input of allochthonous matter in an Atlantic rain forest stream, Ilha Grande-RJ. Acta Limnol. Bras. 17: 167-175.

REZANKA, K. M., AND A. E. HERSHEY. 2003. Examining primary producer-consumer interactions in a Lake Superior tributary using N-15-tracer, grazer-reduction, and nutrient-bioassay experiments. J. N. Am. Benthol. Soc. 22: 371-387.

Rosemond, A. D., C. M. Pringle, A. Ramirez., M. J. Paul, And J. L. Meyer. 2002. Landscape variation in phosphorus concentration and effects on detritus-based tropical streams. Limnol. Oceanogr. 47: 278-289.

---, PRINGLE C. M., AND A. RAMíREZ. 1998. Macroconsumer effects on detritus and detritivores in a tropical stream. Freshwater Biol. 39: 515-524.

SABINO, J., AND C. M. R. CASTRO.1990. Alimentação, período de atividade e distribuição espacial dos peixes de um riacho da floresta atlântica (sudeste do Brasil). Rev. Bras. Biol. 50: 23-36.

SALAS, M., AND D. DudGEON. 2001. Stable-isotope determination of mayfly (Insecta: Ephemeroptera) food sources in three tropical Asian streams. Archiv für Hydrobiologie 151: 17-32.

SilveirA, R. L. M., AND T. P. Moulton. 2000. Modelling the food web of a stream in Atlantic forest. Acta Limnol. Brasil. 12: 63-71.

--- 2002. Modelo de matriz de comunidade em um córrego de Mata Atlântica. $\mathrm{PhD}$ thesis, Universidade do Estado do Rio de Janeiro, Rio de Janeiro, Brasil.

SouzA, M. L., J. C. F. Assis, C. N. Francischetti, T. P. Moulton, M. P. Silveira, AND R. M. L. SILVEIRA. 2001. Indirect effect of fish on shrimp determines sediments, periphyton abundance and macroinvertebrate diversity in two Atlantic forest streams in southeastern Brazil. Bull. N. Am. Benthol. Soc. 18: 260.

---, AND T. P. Moulton. 2005. The effects of shrimps on benthic material in a Brazilian island stream. Freshwater Biol. 50: 592-602.

STEWART, B.A., AND B. R. DAVIES. 1990. Allochthonous input and retention in a small mountain stream, South Africa. Hydrobiologia 202: 135-146.

ThORP, H. J. AND D. M. DELONG. 2002. Dominance of autochthonous autotrophic carbon in food webs of heterotrophic rivers. Oikos 96: 543-550.

Vannote, R. L., G. W. Minshall K. W.Cummins, J. R. Sedell, and C. E. Cushing. 1980. The river continuum concept. Can. J. Fish. Aquat. Sci. 37: 130-137.

VisOnI, S. B., AND T. P. MOULTON. 2003. Effects of shrimp on periphyton and sediments in Atlantic forest streams: an exclusion experiment. Acta Limnol. Bras. 15: 19-26.

WALKER, I. 1988. Study of benthic micro-faunal colonization of submerged litter leaves in the Central Amazonian blackwater stream Tarumã-Mirim. Acta Limnol. Brasil. 2: 623-648.

WeBSTER, J. R., AND J. L. MEYER. 1997. Organic matter budgets for streams: a synthesis. J. N. Am. Benthol. Soc. 16: 141-161.

WRight, M. S., AND A. P. COVICH. 2005. The effect of Macrobrachium exclusion on leaf breakdown rates in a tropical headwater stream. Biotropica 37: 403-408.

YAM, R.S.W., AND D. DudGEON. 2005. Stable isotope investigation of food use by Caridina spp. (Decapoda:Atyidae) in Hong Kong streams. J. N. Am. Benthol. Soc. 24: 68-81. 